\title{
John Stephenson's Secret
}

\section{by Martin A. Entin}

John Stephenson was born in 1797, the youngest son of a Scottish merchant who immigrated to Canada in the late 1700s. He was given a classical education at a Catholic seminary in Montreal, where he achieved scholastic distinction. Stephenson was enrolled in Edinburgh Medical College in 1817. He wrote the graduating thesis in Latin and received his M.D. degree in 1820. On his return to Montreal, he came on staff of the Montreal General Hospital and set up a medical course for training of physicians. In 1829, the Medical Institution was "transferred" to McGill University as the Medical College with Stephenson and three of his colleagues as members of the faculty. Stephenson became a distinguished lecturer in Anatomy, Surgery and Obstetrics. He died in 1843.

When his Latin thesis was translated by Dr. W.W. Francis into English in 1963, it became known that Stephenson was born with cleft of soft palate. He managed to get along during childhood and adolescence with this speech defect. In 1819, he was operated on by Dr. Philibert Roux in Paris who repaired his defect; this enabled Stephenson to attain normal speech. Eventually, he became the respected lecturer at McGill Medical School.

Né en 1798, John Stephenson est le plus jeune fils d'un négociant écossais qui immigre au Canada à la fin des années 1700. Il fait des études classiques remarquées dans un séminaire catholique de Montréal et entre au Edinburgh Medical College en 1817. Il rédige sa thèse en latin et obtient son doctorat en médecine en 1820. À son retour à Montréal, il entre au service de l'Hôpital général de Montréal. Le Medical Institution est «transférée» à l'Université McGill en 1829. Stephenson et trois de ses collègues se joignent au corps professoral de l'Université. Stephenson devient alors un éminent professeur d'anatomie, de chirurgie et d'obstétrique. Il meurt en 1843.

La traduction de la thèse de Stephenson en anglais par le docteur W.W. Francis en 1963, rêvèle que Stephenson avait une fente palatine et qu'il a été affligé d'un défaut de prononciation pendant toute son enfance et son adolescence. En 1819, il est opéré par le docteur Philibert Roux à Paris qui corrige son infirmité, et lui permet de retrouver une élocution normale. Plus tard, il devient un professeur très respecté à McGill.

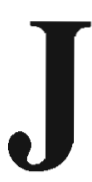

ohn Stephenson, a Scottish merchant, arrived in Canada and established a tobacco mill and small brewery in Montreal one year after the Battle of the Plains of Abraham (1759). His enterprises grew, he prospered and before he died in 1819 he sold the brewery to Thomas Dunn and William Dow who developed it into the exceedingly successful Dow Brewery.'

John, the youngest of his five sons, was born in the winter of 1797. Although of Presbyterian faith, Stephenson's parents enrolled him in the Collège de Montréal, a Catholic seminary where he received a traditional classical education in French. The Sulpician Brothers, directors of the Collège, were so impressed with his ability that it came as no surprise to them when be decided to become a physician. The Collège willingly provided the requisite letter of recommendation stressing his diligence and scholastic competence. $^{2}$

At the end of the 18th century there were no medical schools for the internship training of doctors in Canada and only a few in the United States. Naturally, the type of training that individual doctors received before they started to practice varied tremendously, but a graduating certificate from a medical school was accepted, at this time, as sufficient license to practice medicine.

The Edinburgh Medical School had an excellent reputation during the 18 th and early 19 th century. Students were taught the current theories as well as the more traditional and accepted concepts of medical 


\section{John Stephenson's Secret}

practice. An M.D. degree from Edinburgh gave a distinct advantage to young graduates and assured them a successful career. ${ }^{3}$

On return to their own country, the Edinburgh graduates were often influential in establishing private instruction for the training of aspiring doctors, utilizing methods learned at Edinburgh to establish high standards of practice. (Appendix)

At this time the usual procedure for becoming a doctor was, upon completion of high school, to take up an apprenticeship with a respectable local medical practitioner and subsequently enroll in a medical college, the one at Edinburgh being the most respected and traditionally popular.

In 1815, John Stephenson (Fig. 1) was apprenticed to Dr. William Robertson, a former Army doctor and graduate of Edinburgh. After two years of study, Robertson recommended that Stephenson enroll in the Edinburgh Medical College. ${ }^{4} \mathrm{He}$ attended Edinburgh University in 1817 where he encountered a childhood friend, Andrew Holmes, who was also pursuing a career in medicine. Stephenson attended to his medical studies with great diligence for the next couple of years. Toward the end of the third year, he and Holmes spent a few weeks studying with Professor P.J. Roux, the renowned surgeon at La Charité Hospital in Paris. One year later, Stephenson fulfilled the graduation requirements of Edinburgh Medical College-he completed and submitted a thesis ${ }^{5}$ and passed his final exams (Fig. 2). Having decided to specialize in surgery, he was now eager to return to Montreal and, in the best Edinburgh tradition, contribute to the education and training of Canadian doctors.

During this period, hospital facilities for the English community of Montreal were inadequate. A small rented building on Craig Street was a temporary measure while the Protestant citizens of Montreal were collecting donations for the establishment of a new hospital on Dorchester Street East scheduled to open in the Spring of 1822 .

Stephenson persuaded Andrew Holmes, his mentor William Robertson and another former Army doctor, William Caldwell, all Edinburgh graduates, to serve on the staff of the temporary hospital. Stephenson assumed the duties of a house surgeon. ${ }^{6}$
The new hospital, named the Montreal General Hospital, was opened in May 1822. It accommodated, without religious discrimination, one hundred patients and it was dedicated to "the relief of the distressed poor". "Its Medical Board was comprised of the four Edinburgh graduates who staffed the former hospital on Craig Street. Following the Edinburgh model, the Board proposed that the hospital also serve as a "medical school". Student physicians would be admitted to the wards in order to take advantage of on-site teaching and study. ${ }^{8}$ Within three months of the opening of the new hospital, Stephenson placed a notice in the Montreal Gazette announcing that he would begin lectures in Anatomy and Physiology on October 1, 1822 and in Surgery on March 1, 1823.

The Montreal General Hospital medical staff appointed Holmes and Stephenson to draw up a document justifying the establishment of a medical school and setting forth its curriculum. ${ }^{9}$ The subsequent document recommending the establishment of a "Medical Seminary" in the style and tradition of the Edinburgh Medical School and requesting a Royal Charter was forwarded to Lord Dalhousie, the Governor-in Chief. In October, 1822 Stephenson established the Medical Institution (Fig. 3), a facility for the training of prospective doctors.

There was a lengthy delay in the granting of the Charter since the Medical Institution could claim no association or affiliation with a university and had no long-term financial support.

Coincidentally, in 1813, James McGill, a Glaswegian who had emigrated to Canada in 1766, willed his fortune toward the establishment of a university to be named after him. A Royal Charter was granted on March 21, 1824. One of the conditions of the will was that a functioning college be established by 1829 otherwise the legacy would revert back to the estate. ${ }^{10}$

In 1829 , a compromise was reached between the Board of the Montreal General Hospital and the estate of James McGill. The Medical Institution acquired both a charter and foundation while McGill University received a prestigious, functioning Medical Faculty. William Robertson was appointed Professor of Medicine and the other three members were listed as lecturers in the new McGill Medical Faculty. ${ }^{11}$ 


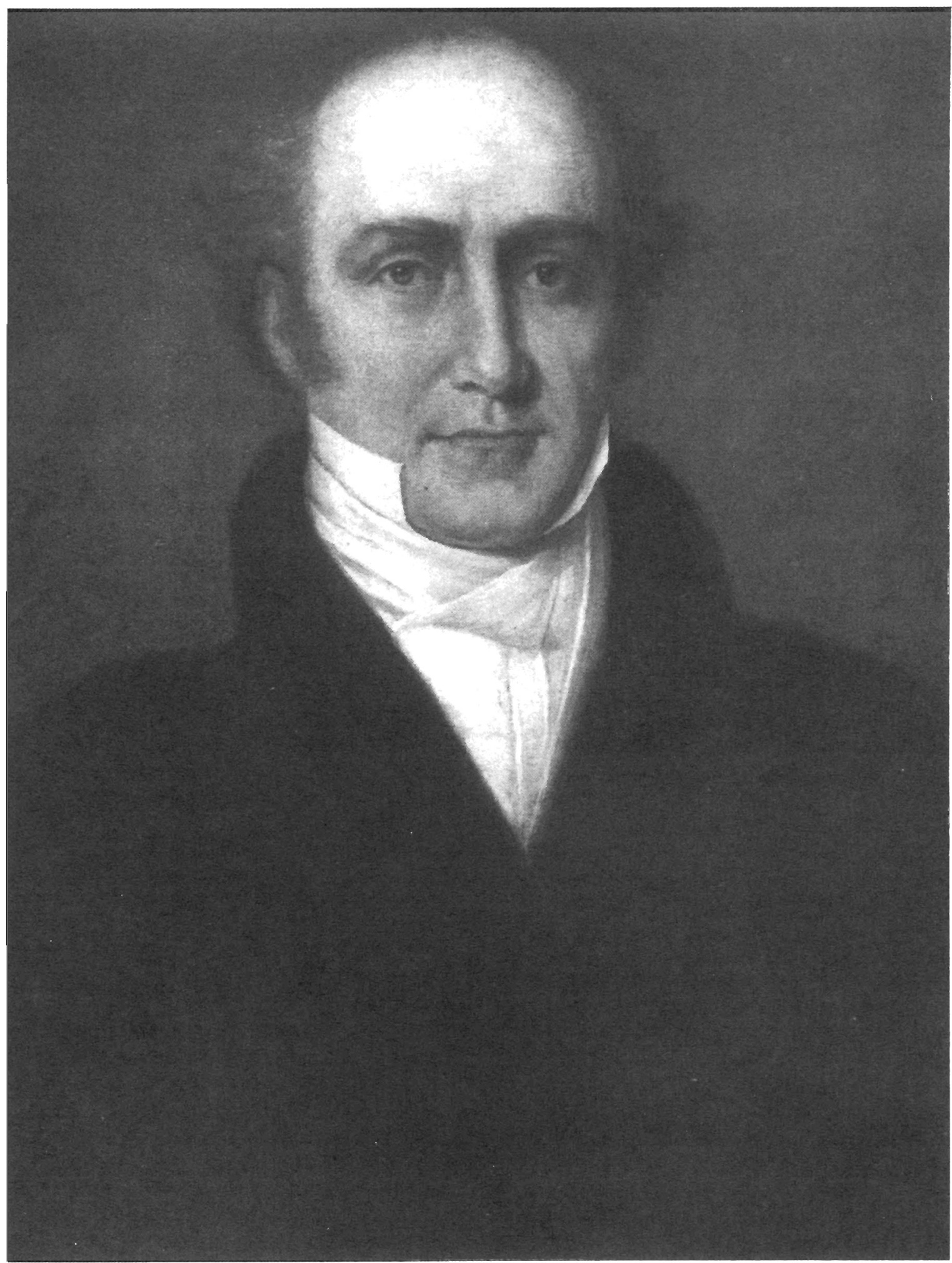

Figure 1. John Stephenson 1797-1842. 


\section{John Stephenson's Secret}

This historic event occurred on June 29, 1829 in Burnside House, the country residence of James McGill. The occasion was the first meeting of the Governors of the Corporation of McGill College and it assured the survival of the Medical Faculty and of McGill University. ${ }^{12}$ Stephenson's participation in the Medical Institution and its subsequent "engrafting" to McGill has been historically acknowledged and has become a prominent event in the history of McGill University. (Fig. 4) Yet, only a few were aware of the harsh physical and psychological trauma that Stephenson had recently overcome. Stephenson had been born with a severe speech defect which had frustrated his childhood, adolescence and early adulthood.

Only years later when William Willoughby Francis, custodian of the Osler Library, translated Stephenson's thesis (1820) from the Latin, did the details of Stephenson's congenital deformity come to light. Francis' English translation was published in 1963. ${ }^{13}$

By curious coincidence, Alistaire B. Wallace, a leading plastic surgeon at the University of Edinburgh, stumbled upon another copy of Stephenson's thesis in the Old College Library of the university. Referring to a translation of the thesis by W. McLean Dewar, Wallace presented a paper to the British Association of Plastic Surgeons in London in December 1963. ${ }^{14}$

These two independent discoveries, continents apart, helped to illuminate curious events in Stephenson's childhood and adolescence: Stephenson's parents' insistence in enrolling their son in the Roman Catholic Collège de Montréal became more understandable; references to the nasal quality of Stephenson's speech, especially when he was excited, became more comprehensible; ${ }^{\text {is }}$ and Stephenson's energetic drive to establish the Montreal Medical Institution and his compulsion to train Canadian doctors when he returned to Montreal, took on added psychological significance.

Stephenson's thesis had presented the details of his congenital anomaly and of the sequelae in the form of a clinical report giving a thorough account of his struggle to communicate during his childhood and adolescence. $^{16}$

He had been born with a cleft of the soft palate which is characterized by the inability to swallow fluid while in a horizontal position. His mother's ingenuity in holding her son up-right while breast feeding was crucial to his survival. He was very late in talking and his speech was difficult to understand. During these traumatic years, Stephenson had always hoped that some means could be found to repair the damage. Eventually, he accepted his lot with resignation. ${ }^{17}$

Stephenson's account of his studies at the Edinburgh Medical School stressed the facilitating presence of his friend Andrew Holmes. Stephenson had panicked at the thought of confronting his professors who would question him in Latin and expect a response in kind. It was Holmes who made contact with the professors alerting them to Stephenson's speech impediment. He also helped Stephenson find lodging near the university. Stephenson passed two years of his medical studies without difficulty. $\mathrm{He}$ projected an easy-going disposition which permitted him to make friends easily in spite of his imperfect speech. Faced with the prospect of oral examinations, he became concerned about matriculation. Holmes made inquiries at the Registrar's office and was told that Stephenson could make arrangements to take his examination in writing.

During his course of study in Paris with Dr. Roux, Stephenson consciously refrained from asking questions. However, towards the end of the course, Dr. Roux became aware of his student's distorted speech and Stephenson revealed that he was suffering from a congenital anomaly of the soft palate. Dr. Roux quickly offered to surgically correct it. Stephenson's hope of attaining normal speech was re-awakened and he accepted the offer with alacrity. The operation, which lasted one hour, without anaesthetic, strained Stephenson's stoicism. However, he made a great effort to help Roux complete the repair without mishap.

The serendipitous encounter with Dr. Roux in 1819 wrought a metamorphosis. Within a fortnight Stephenson's speech was almost normal. ${ }^{18} \mathrm{He}$ was able to present an account of his operation to the Academy of Science in Paris at Dr. Roux's request. ${ }^{19}$ While training his palate and voice to attain normal articulation in English, Stephenson acquired fluency in Latin as well.

The main object in surgical repair of cleft of soft palate is to restore normal speech. Abnormal speech is 


\section{John Stephenson's Secret}

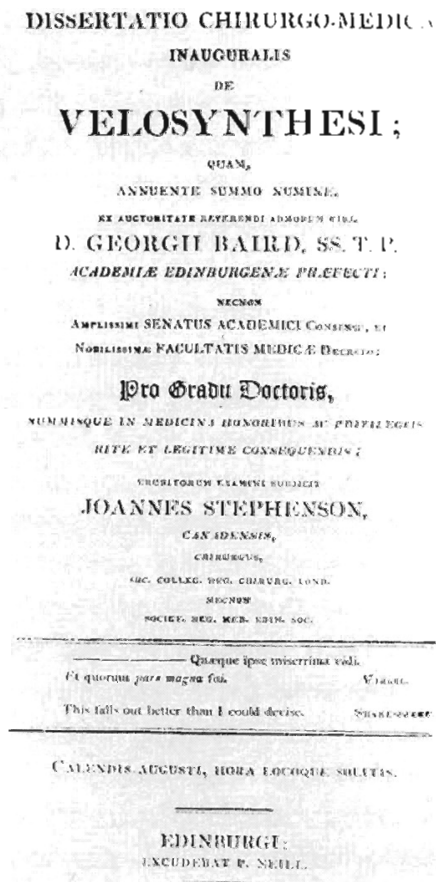

Figure 2. Stephenson's Graduation Thesis, 1820.

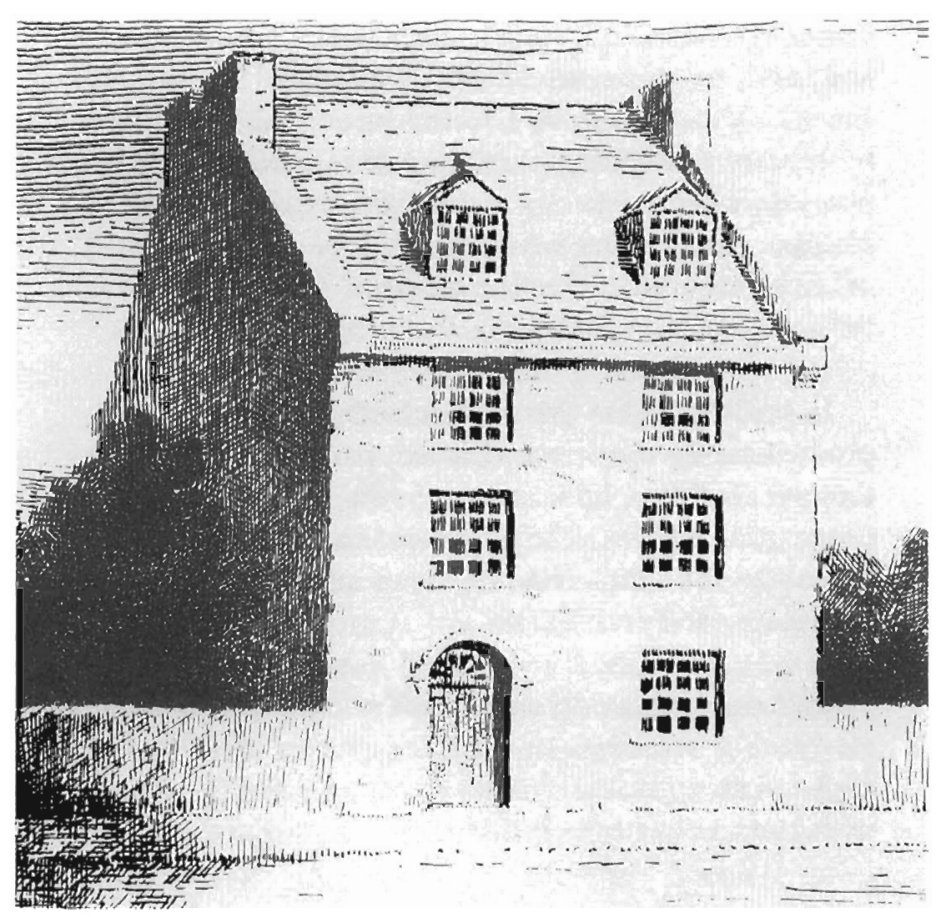

Figure 3. Montreal Medical Institution, 20 St. James Street, Montreal (ca. 1824).

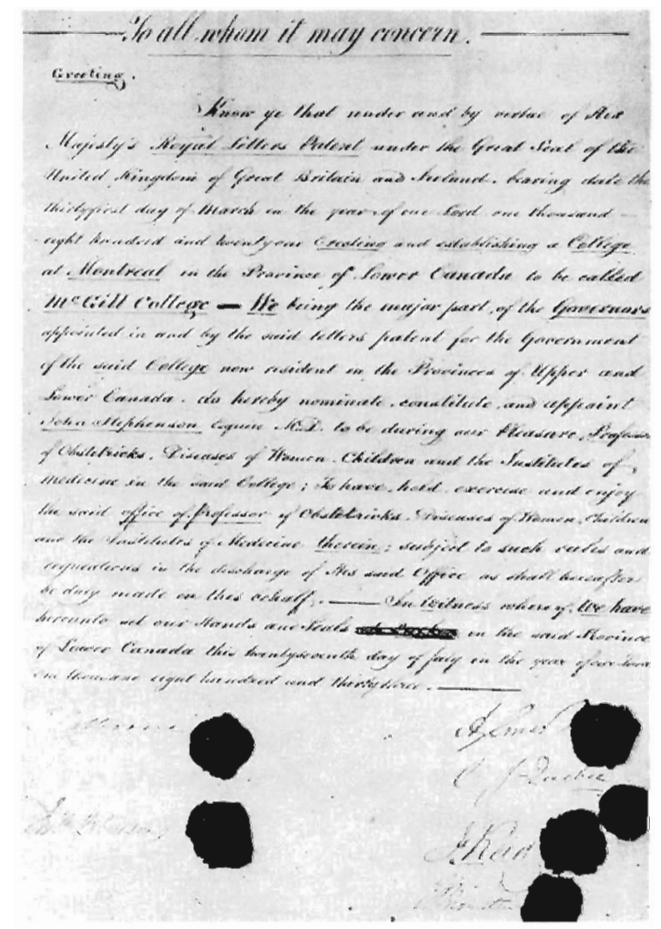

Figure 4. Royal Letters Patent mentions the establishment of McGill College on March 31, 1821, and certifies the appointment of John Stephenson, M.D., as Professor of Medicine at McGill College on July 27, 1833. 


\section{John Stephenson's Secret}

caused by the inability to produce closure between nasal and oral cavities, an action mandatory for normal speech. This closure is effected in normal individuals by two mechanisms: the soft palate is elevated and the pharynx is constricted by synergistic muscle action. The result is that the oral cavity and nasal cavity are closed off from each other for that moment. Obviously, when the soft palate is split (cleft), that action is impossible. ${ }^{20}$

In addition to the closure mechanism, normal speech production involves coordinated participation of the tongue, larynx, lips, and of the nasal and oropharyngeal cavities. The process of speech also requires a subtle coordination of respiration, phonation, resonance, and articulation.

Patients with unoperated cleft of soft palate make predictable articulation errors known as the "typical cleft palate speech", characterized by nasality and, in extreme cases, a speech that is difficult to understand.

In persistent attempts to improve their speech, these patients acquire certain speech habits which involve the use of auxiliary neck muscles and the muscles of the pharynx. After surgical repair of the soft palate, speech habits tend to persist although they are no longer appropriate. It requires assiduous training to overcome these long standing habits. ${ }^{21}$

Stephenson was Dr. Roux's first patient to undergo repair of the cleft of soft palate. The first recorded surgical attempt to do so had been carried out by LouisGuillaume Le Monnier in $1766 .^{22}$ Le Monnier was a practising dentist who carried out an ingenious repair of his patient's soft palate by inserting several sutures into the separated halves of the split palate. He "freshened" the margins with thermal cautery. This process of freshening inevitably left residual "cooked" tissue along the margins. There is no record of the success of this procedure. $^{23}$ The first successful closure of the soft palate was described by German surgeon Dr. Carl Ferdinand von Graefe in $1817 .{ }^{24}$

Roux was unfamiliar with both Le Monnier's or von Graefe's reports. His surgical procedure was similar to that of Le Monnier's, but he used a scalpel to produce a freshened bleeding surface of the two margins of the split palate. This procedure permitted accurate junction and subsequently good healing of the split palate.
When Stephenson returned to the Medical School in Edinburgh, he not only had to re-educate his repaired soft palate to articulate more normally, but he also had to eliminate the acquired mannerisms and undesirable patterns of speech, which had inevitably developed in his effort to speak more normally. ${ }^{25}$

Stephenson cogently summarized the problematic situation in his thesis: "The repaired instrument (i.e. soft palate) is not yet fulfilling its proper duties nor giving the belp it should to my vocal faculty. Who can deny the all-importance of habit? ${ }^{126}$

His thesis also understates the amount of discipline and of the effort that this required. Anyone who has had to supervise such patients is well aware of the Herculean effort involved. ${ }^{27}$

Progress was slow but he gradually overcame many previous handicaps: he could play a wind instrument which he could not before and to his great relief, when he had to expel the stomach contents, the vomitus did not come through the nostrils. For the first time in his life he was able to experience the joy of drinking from a brook prostrate on his stomach and was also able to inflate a balloon. ${ }^{28}$

Stephenson received permission to write his thesis on the repair of his soft palate. Having gone through the experience, he felt that he was justified in making certain suggestions regarding the operative procedure. He made several comments about improving the needle drivers; interposing a hard, rubbery substance under the sutures to prevent getting buried into the tissue; avoiding talking and eating during the first few days. Other remarks included the rate of incidence of this condition.

Stephenson's description of his operation preceded his surgeon's report by six years (1825). Stephenson called his procedure Velosynthesis, from the Latin for, "soft palate" (velum) and from the Greek for, "repair" (synthesis). Roux's own account favoured the term staphyloraphie. ${ }^{29}$

It is interesting to note that Stephenson's Latin Graduation Thesis, Velosynthesis, was acquired by McGill University but remained unread for 135 years. Its unusual contents did not become public knowledge 
until Dr. William Francis decided to translate it into English.

Stephenson's account presented in his Thesis is somewhat different from the recounting of events after his return from Edinburgh Medical School to Montreal as presented by several commentators. ${ }^{30}$ In 1821 , Stephenson was a transformed person; he was outgoing, became a popular surgeon, founded the Medical School, and became a teacher and administrator.

When he returned to Montreal, only his family, Andrew Holmes, and Dr. Robertson had been aware of his speech handicap. It had been a well-kept secret for fear of embarrassing him.

It is extraordinary that, at the end of the 18th century, an infant, born with a cleft of the soft palate managed to live and thrive, overcoming the odds against his survival due to infection and malnutrition. Stephenson's perseverance and eventual success as a physician can be attributed to his parents' constant encouragement and their choice of the Collège de Montréal which helped create a sense of confidence and self-esteem in the afflicted young man. ${ }^{31}$

His Edinburgh years, sustained by the aid and friendship of Andrew Holmes, further contributed to his self-confidence and optimism. It is to Stephenson's credit that after his cleft palate operation he singlebandedly overcame his speech defects and improved his articulations.

It is a unique event when both surgeon and patient relate their impression of the same surgical procedure. Stephenson's account of his operation in 1819 was complemented by Roux's published report of this procedure in $1825^{32}$ and by Roux's later reflections on this subject in 1854 .

You know also that it was on a young Canadian physician (his name was Stephenson) on whom I did for the first time the repair procedure. He was the first man to benefit from the advantages of this surgical procedure. I have described in my report on staphylorhaphy (published in 1825). I have never seen a cleft of the palate alone and now (since this first case) I have seen several hundreds of this type. I recognised it from the few descriptions in scientific literature under the name of bifid uvula. Mr. Stephenson and myself were able to experience a success that we had little expected. The continuity of the two parts of the palate was so complete and so perfect and the speech was so improved (later it became still better) that Mr. Stephenson, eleven days following surgery, was able to read to our Academy of Science a short description of the new repair of which he was the subject. You also know that Mr. Stephenson, having left me for his graduation in Edinburgh, came back to Paris after several months and stayed some time with me before going back to his native land. Already at that time his speech was modified and improved. As I learned later, time led to further progress in the education of his palate and his speech became more and more perfect. This must have been so, since Mr. Stephenson chose a teaching career and wrote a few years later that he had been elected Professor of Anatomy of the Faculty of Medicine. " 33

At the time of writing these reminiscences, Roux had done 140 repairs of soft palate in 30 years. One interesting comment that Roux made was as follows:

The name of Mr. Stephenson is associated with staphylorhaphy (repair of soft palate) and it will probably never be forgotten in the history of this operation... ${ }^{34}$

Now, without a speech handicap, Stephenson was able to devote himself to his practice and to medical education with all the energy and zeal of a man with a mission.

Stephenson died February 2, 1842 at the age of 45, yet in those 22 years in Montreal "he had achieved more than most men achieve in a long lifetime". ${ }^{35}$ 
APPENDIX

EDINBURGH GRADUATES WHO PRACTILED IN LOWER CANADA: 2800-1828

\begin{tabular}{|c|c|c|c|c|c|c|c|}
\hline NAME & $\begin{array}{l}\text { COUNPRY of origris } \\
\text { (Span of life) }\end{array}$ & $\begin{array}{l}\text { APRENTICESAYP OR } \\
\text { ARMY SERVICE }\end{array}$ & $\begin{array}{l}\text { YEAR CRADUATED FROM } \\
\text { EDINGURGG }\end{array}$ & $\begin{array}{l}\text { LICENCE } \\
\text { GRANTED }\end{array}$ & $\begin{array}{l}\text { MGA STAFE } \\
\text { NEDTCAL } \\
\text { INSTITUTYOH }\end{array}$ & $\underset{\text { FACULTY }}{\text { MCGILI MEICAL }}$ & $\begin{array}{c}\text { PRYVATE } \\
\text { PRACTIEE } \\
\text { IN QUEBEC }\end{array}$ \\
\hline Pierre Beaubien & Lower Canada & & $?$ & 1828 & & & \\
\hline Charles slake & & $\begin{array}{l}\text { Surgeon to } \\
\text { Garrison ti.11 } 1781\end{array}$ & ? & & & & \\
\hline Hugh Bone & & & ? & & & & \\
\hline william caldwell & Scottand $(-1833)$ & $\begin{array}{l}13 \text { Regiment } \\
\text { Dragoons }\end{array}$ & ? & $?$ & $\begin{array}{l}1821 \\
1823 \\
\end{array}$ & $\begin{array}{l}\text { St. Andrew } \\
\text { Montreal } 1819\end{array}$ & 1829 \\
\hline Peter Dieh 1 & Lower Canada & $\begin{array}{l}\text { with Dr. Charles } \\
\text { Blake } 1800-1807\end{array}$ & 1809 & 2809 & & $\begin{array}{l}\text { Partner with } \\
\text { Dr. c. Arnoldi } \\
\text { loig. Arnold }\end{array}$ & \\
\hline James Douglas & Scot 1 and $\{2800-\}$ & & $\begin{array}{l}1820 \\
\text { classmate of } 3 \text {. Stephenson }\end{array}$ & 1926 & & Quebec 1828 & \\
\hline Thomas Fargues & & & 1813 & 1814 & & & $\begin{array}{r}1823-29 \\
\end{array}$ \\
\hline Andrew Holmes & $\begin{array}{l}\text { Cadiz, Spain } \\
\text { (English Parents) }\end{array}$ & $\begin{array}{l}\text { Dr. C. Arnoldi } \\
1811-1816\end{array}$ & 1819 & 1818 & $\begin{array}{l}1822 \\
1823\end{array}$ & 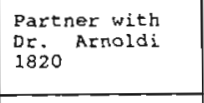 & $\begin{array}{l}1829 \\
1842 \\
\text { Professor } \\
1860 \text { Dean } \\
\end{array}$ \\
\hline Jacque Labrie & $\begin{array}{l}\text { French, from Lower } \\
\text { Canada } \\
(-1883)\end{array}$ & & $\begin{array}{c}1808 \\
\text { (Eirste French CanadLan) }\end{array}$ & & & $\begin{array}{l}\text { St. Eustache } \\
\text { Quebec }\end{array}$ & \\
\hline Archibald Rae & & & $?$ & 1823 & & & \\
\hline Racy & & & $?$ & & & $\begin{array}{l}\text { Practice with } \\
\text { Dr. Douglas } \\
1846 \\
\end{array}$ & \\
\hline William Robertson & Scotland $(1784-1$ & $48 \mathrm{th}$ Regiment & -1804 & 1828 & 2823 & Montreal 1815 & 1829 \\
\hline John Stephenson & Montreal $(1797-1842)$ & $\begin{array}{l}\text { Dr. W. Robertson } \\
\{1815-1817\}\end{array}$ & 1820 & 1821 & $\begin{array}{l}1820 \\
1823\end{array}$ & & 1829 \\
\hline J.B.C & & & & 1822 & & & \\
\hline
\end{tabular}




\section{John Stephenson's Secret}

\section{Notes}

1. Whiteford, W.M. "Reminiscences of Dr. John Stephenson, One of the Founders of McGill Medical Faculty". Canadian Medical and Surgical Journal v.11 (1883):728-31.

2. Whiteford (1883), p.728.

3. Rendall, J. "The Influence of Edinburgh Medical School in America in the 18th Century". Edinburgh Medical Journal (April, 1923):95-124.

4. Abbott, M.E. "The Faculty of Medicine of McGill University". Surgery, Gynaecology and Obstetrics v.60 (1935):242-53.

5. Stephenson, John. De Velosynthesis; a Graduation Thesis in Latin, submitted to the Edinburgh Medical College, August $1,1820$.

6. Abbott, M.E. "A Historical Sketch of the Medical Faculty of McGill University". Montreal Medical Journal v.31 (1902):563.

7. Abbott (1902), p. 571.

8. Abbott (1902), p. 571.

9. Abbott (1935), p. 243.

10. Abbott, M.E. History of Medicine in the Province of Quebec. Montreal: McGill University, 1931, p.60.

11. Abbott, M.E. (1931), pp. 55, 59.

12. Abbott (1931), p. 60.

13. Stephenson, John. "Translation of Velosynthesis from Latin by W.W.Francis. Repair of Cleft Palate by Philibert Roux in 1819". Journal of the History of Medicine and Allied Sciences v.18 (1963):209-19.

14. Wallace, A.B. "Canadian-Franco-Scottish Co-operative: A Cleft Palate Story". British Journal Plastic Surgery v.19 (1966):1-13.

15. Workman, J. Letter to Sir William Osler. August 10, 1883. Written for the purpose of clarifying some errors in Whiteford (1883). McGill Osler Library. Archives. (J. Workman, 1805-1894). Workman was apprenticed to Stephenson for five years.

16. Stephenson, John. De Velosynthesis; A Graduation Thesis in Latin submitted to the University of Edinburgh Medical College, August 1, 1820. Archives of the Osler Library. McGill University.

17. Stephenson, John. "Repair of Cleft Palate by Philibert Roux in 1819". Plastic and Reconstructive Surgery v.47 (1971):281. (Comments by Dr. Martin Entin)

18. Stephenson (1971), p.280.

19. Roux, P.J. "Observation sur une division congenital du voile du palais et de une luette guerie du moyen d'une operation". Journal Universel de Science Medicale v.15 (1819):356.

20. Johnson, W. et al. Diagnostic Methods of Speech Pathology. New York: Harper and Row, 1963, pp. 50ff.

21. Wallace (1966), p.8.

22. Stark, Richard. "Cleft Palate." In Reconstructive Plastic Surgery, edited by J. Converse. v. 3. Philadelphia: Saunders,
1968 , p. 1416. Stark refers to Louis-Guillaume Le Monnier's Traité des principaux objets de médecine avec un sommaire. Paris: Lacombe, 1766.

23. Stark, Richard (1968), p. 1416.

24. Von Graefe, Dr. Carl Ferdinand. "Kurze Nachrichten une Auszuge". Journal der Practischen Arzneykunde und Wundarzneykunst v.44 pt.1 (1817):116.

25. Johnson, W. (1963), pp. $50 \mathrm{ff}$.

26. Stephenson (1971), p.281.

27. Stephenson (1971), p.282. Dr. Entin has had extensive experience in post-operative management of patients with cleft palate at the Royal Victoria Hospital and at the Shriners Hospital, Montreal during the 1960 s and 1970s.

28. Stephenson (1971), p.281.

29. Roux, P.J. "Mémoire sur la staphyloraphie, ou il suture a voile du palais". Archives des Sciences Medicales v.7 (1825):516-538.

30. Abbott (1902); Abbott (1931); Abbott (1935) and Workman (1883). Neither were aware of Stephenson's congenital defect nor of the operative repair in 1819.

31. Roland, C.J. "John Stephenson". In Dictionary of Canadian Biography, v.7, pp.824-25. Toronto: University of Toronto Press, 1988. In 1821, Stephenson was appointed Physician to the Sulpicians in Montreal and retained that appointment until his death in 1842, repaying in service what the College had contributed in character-building.

32. Roux (1825).

33. Roux (1825).

34. Letters dedicated to Mr. William Lawrence, Surgeon Bartholomew's Hospital, London. (Letter no.7). In Roux, P.J. Quarante Années de Pratique Chirurgicale, v.1: Reparative Surgery. Paris: Librairie de Victor Masson, 1854. Cited in Wallace, A.B. (1966), p.13.

35. Frost, Stanley B. McGill University: For the Advancement of Learning, V.1:1801-1895. Montreal: McGill-Queens University Press, 1980, p.127.

\section{Acknowledgement}

The author wishes to express his appreciation to Mrs. Jo Currie, Assistant Librarian, Special Collections, Edinburgh University Library for ferreting out the valuable material reflecting on John Stephenson's life and studies while in Edinburgh Medical College. To Dr. and Mrs. Charles Cahn and to Dr. Annmarie Adams, for reading the manuscript and their suggestions. 